KINDERGARTEN: Journal of Islamic Early Childhood Education

Homepage: http:// ejournal.uin-suska.ac.id/index.php/KINDERGARTEN

Vol. 2, No. 1, April 2019, Hal. 35-57

Email:jcie.piand@,uin-suska.ac.id

p-ISSN 2621-0339

e-ISSN 2621-0770

\title{
Pengaruh Regulasi Emosi Single Mother terhadap Penerimaan Diri Pada Anak Se-Kecamatan Rumbai Kota Pekanbaru
}

\author{
Rany Handri Yanti ${ }^{1}$, Ria Novianti ${ }^{2}$, Enda Puspitasari ${ }^{3}$ \\ 1 Program Studi Pendidik Guru Pendidikan Anak Usia Dini, Universitas Riau \\ 2 Program Studi Pendidik Guru Pendidikan Anak Usia Dini, Universitas Rian \\ ${ }^{3}$ Program Studi Pendidik Guru Pendidikan Anak Usia Dini, Universitas Riau \\ rany.handryanti1218@gmail.com, rianovianti.rasyad@gmail.com, \\ enda.puspitasari@gmail.com
}

\begin{abstract}
This research aims to determine the level of influence of the emotional regulation of single mother to the acceptance of children in the sub-district Rumbai Pekanbaru City. The samples in this study were the son and single mother of the sub-district Rumbai Pekanbaru which amounted to 22 children and mothers. The method used is the correlation of Chi Square to see the influence between the regulatory variables of single mother's emotions towards child acceptance. The data collection techniques used are questionnaires in the form of Likert scales. Data analysis techniques using scale trials and statistical method analysis. Visible from the overall amount of the emotional Regulation indicator single mother can be concluded that the emotional regulation is in good category with a percentage of $71.83 \%$, while on the child's self-acceptance indicators are in a very good category with Percentage of $81.31 \%$. From the results of the test, the results of Chi Square were obtained a probability figure of 0.044 which is $0.044<0.05$, then Ho rejected and $\mathrm{Ha}$ accepted. This means that there is a significant influence between single mother's emotional regulation of child acceptance.
\end{abstract}

Keywords: Single mother, Emotional Regulation, Child, Self-Acceptance

\begin{abstract}
Abstrak. Penelitian ini bertujuan untuk mengetahui tingkat pengaruh regulasi emosi single mother terhadap penerimaan diri pada anak se-Kecamatan Rumbai kota Pekanbaru. Adapun sampel dalam penelitian ini adalah anak dan ibu tunggal se-kecamatan Rumbai kota Pekanbaru yang berjumlah 22 anak dan ibu. Metode yang digunakan yaitu korelasi Chi Square untuk melihat pengaruh antara variabel regulasi emosi single mother terhadap penerimaan diri anak. Teknik pengumpulan data yang digunakan yaitu kuesioner dalam bentuk skala Likert. Teknik analisa data menggunakan uji coba skala dan analisa metode statistik. Terlihat dari jumlah keseluruhan indikator regulasi emosi single mother dapat disimpulkan bahwa regulasi emosi berada dalam kategori baik dengan persentase $71,83 \%$, sedangkan pada indikator penerimaan diri anak berada dalam kategori sangat baik dengan persentase 81,31\%. Dari hasil uji Chi Square diketahuui hasil analisis diperoleh angka probabilitas sebesar 0,044 dimana $0,044<0,05$, maka Ho ditolak dan Ha diterima. Artinya terdapat pengaruh yang signifikan antara regulasi emosi single mother terhadap penerimaan diri anak.
\end{abstract}

Kata Kunci: Single Mother, Regulasi Emosi, Anak, Penerimaan Diri 


\section{PENDAHULUAN}

Sebuah keluarga pada umumnya terdiri dari ayah, ibu, dan anak, namun pada kenyataan sekarang ini banyak ditemukan keluarga yang berstatuskan sebagai orangtua tunggal (single parent). Single parent secara umum adalah orangtua tunggal yang mengasuh anaknya seorang diri tanpa bantuan pasangan dan memiliki kewajiban yang sangat besar dalam mengatur keluarganya, adapun permasalahan yang dialami single parent lebih rumit dibandingkan keluarga utuh lainnya, hal ini dapat terjadi akibat kematian seorang suami ataupun perceraian. Keluarga utuh memang lebih beruntung dibandingkan keluarga yang tidak lengkap layaknya yang telah dialami oleh seorang single mother, ia yang merasakan kesedihan mendalam. Masalah yang timbul pada single mother yaitu menjalankan peran ganda dalam keluarganya, selain menjadi seorang ibu yang memberikan perhatian kepada anaknya, ia juga menggantikan peran sebagai seorang ayah untuk mencari nafkah bagi keluarganya. Keadaan ini mengharuskan adanya kematangan dalam pribadi seorang single mother, terutama pada kestabilan emosinya. Kondisi yang terjadi pada anak yang tidak memiliki orangtua lengkap akan merasa kurangnya perhatian, hal ini tidak menutup kemungkinan bahwa anak akan mengalami masalah dalam penerimaan diri.

White (2012) mengatakan terdapat proses-proses yang harus dilalui oleh seseorang untuk dapat menerima dirinya, yaitu seseorang harus mampu mengenal dirinya sendiri, menahan diri dari pola kebiasaan yang lalu, mengubah emosi dari suatu peristiwa yang terjadi didalam kehidupannya, serta mereka mampu melepaslan segala kejadian-kejadian yang pernah ada dalam kehidupannya. Penerimaan diartikan sebagai sikap yang mampu memandang dengan jernih dan menerima keadaan yang ada dengan segala kelebihan dan kekurangan. Penerimaan diri (self-acceptance) ialah suatu kemampuan individu untuk dapat melakukan penerimaan terhadap keberadaan diri sendiri

Dari hasil observasi peneliti menemukan permasalahan penerimaan diri anak dari single mother yaitu, (1) anak cenderung bersikap tidak realistis terlihat ketika ditanya perihal ayah, ia kerap menjawab ayah tidak mau berteman dengannya, dananak tidak memiliki pendirian terhadap dirinya sendiri, terlihat ketika salah satu temannya mengajak untuk tidak bermain dengan teman yang lain, (2) anak menilai bahwa dirinya berbeda dengan anak yang lain, terlihat perilaku anak yang berdiam diri dikelas saat perayaan hari ayah disekolah, serta anak cenderung tidak mampu mengekspresikan kelebihan yang ia miliki, (3) anak cenderung menyalahkan ibunya bahwa ibunya lah yang menjauhkan ia dari ayahnya. Untuk itu sangat dibutuhkan regulasi emosi pada single mother sebagai pengontrol diri, sehingga dengan kemampuan regulasi emosi yang dimiliki tidak membawa dampak 
buruk bagi perkembangan psikologis anak. Untuk mendapatkan regulasi emosi yang baik, hal yang harus dilakukan individu yaitu pengenalan terhadap dirinya sendiri. Penelitian yang telah dilakukan oleh Ria Novianti (2018) dalam jurnalnya menyatakan bahwa secara umum peran orangtua dalam menumbuhkan resiliensi anak adalah mutlak terutama pada anak usia dini, hal ini dikarenakan pada anak usia dini diintervensi lingkungan luar terhadap anak masih minimal dan orangtua lah yang memiliki pengaruh terhadap perkembangan anak, sedangkan temuan dalam penelitian ini menemukan bahwa anak yang berada pada posisi anak dari single mother sangat membutuhkan peran orangtua agar ia dapat menerima posisi dirinya dengan baik. Keadaan ini mengharuskan adanya kematangan dalam pribadi seorang single mother, terutama pada kestabilan emosinya. Kondisi yang terjadi pada anak yang tidak memiliki orangtua lengkap akan merasa kurangnya perhatian, hal ini tidak menutup kemungkinan bahwa anak akan mengalami masalah dalam penerimaan diri.

Menurut Gross \& Thompson (2006) Regulasi emosi melibatkan proses intrinsik maupun ekstrinsik. Proses intrinsik adalah bagaimana cara seseorang mengeola emosi yang timbul dalam dirinya sendiri; sedangkan proses ekstrinsik adalah bagaimana cara seseorang memengaruhi emosi orang lain. Hasil dari pada kedua subjek yang menyatakan bahwa munculnya emosi negatif, maka ditemukannya permasalah regulasi emosi pada single mother, selanjutnya peneliti tertarik untuk melihat bagaimana single mother meregulasi dirinya dalam menghadapi permasalahan hidup. Dari hasil yang diteliti ditemukan permasalahan regulasi emosi, yaitu (1) single mother merasakan adanya tekanan dalam hidupnya sehingga sulit mengontrol emosinya. (2) Ketika single mother berada dalam permasalahan ia cenderung tidak bisa mengontrol emosinya dengan memperlihatkan mimik wajah yang menandai ia sedang dalam keadaan stress dan sulit untuk peka terhadap perasaan orang lain. (3) karenasingle mother menyelesaikan permasalahan nya sendiri, single mother kerap ceroboh dalam menyelesaikan permasalahan yang dihatapi, dalam arti terburu-buru. (4) single mother sulit untuk menerima perubahan yang datang pada dirinya. (5) single mother kerap merasakan keputus asaan karena harus menanggung biaya, kebutuhan pada keluarganya seorang diri. (6) single mother sulit menerima posisinya pada lingkungan tempat tinggalnya, karena beranggapan bahwa dirinya berbeda dengan keluarga lainnya.

Penelitian ini memiliki rumusan penelitian sebagai berikut a. Bagaimanakah penerimaan diri anak single mother se-kecamatan Rumbai kota Pekanbaru? b. Bagaimanakah regulasi emosi single mother se-kecamatan Rumbai kota Pekanbaru? c. Apakah ada pengaruh yang signifikan antara regulasi emosisingle motherterhadap penerimaan diri anak se-kecamatan Rumbai kota Pekanbaru. 
Sesuai dengan permasalahan yang ada, maka tujuan penelitian ini yaitu : a. Untuk mengetahui penerimaan diri anak single mother se-kecamatan Rumbai kota Pekanbaru. b. Untuk mengetahui regulasi emosi single mother se-kecamatan Rumbai kota Pekanbaru. c. Untuk mengetahui seberapa besar pengaruh yang signifikan antara regulasi emosi pada single motherterhadap penerimaan diri anak se-kecamatan Rumbai kota Pekanbaru.

Manfaat penelitian ini adalah 1. manfaat teoritis (a) sebagai sumbangan pemikiran orangtua terhadap regulasi emosi single mother dengan penerimaan diri anak single mother. (b) bagi peneliti selanjutnya menambah pengetahuan dan pengalaman bagi peneliti tentang pengaruh regulasi emosi single mother terhadap penerimaan diri anak single mother. 2. Manfaat Praktis (a) bagi single mother (ibu tungal) dapat memberikan pemahaman yang lebih mendalam mengenai konsekwensi pilihan hidup menjadi wanita sebagai orangtua tunggal. (b) bagi masyarakat, dapat membantu masyarakat untuk lebih baik lagi dalam memerhatikan warganya terutama pada single mother, serta memberi dukungan kepada single mother dan anaknya.

\section{METODE PENELITIAN}

Penelitian ini menggunakan metode kuantitatif dengan jenis penelitian korelasi yang dilanjutkan dengan menghitung besarnya pengaruh antara variabel bebas terhadap variabel terikat. Variabel yang dihubungkan dalam penelitian ini adalah regulasi emosi single mother sebagai variabel (X) dan penerimaan diri sebagai variabel $(Y)$. Penelitian ini dilaksanakan di Kecamatan Rumbai kota Pekanbaru pada bulan April hingga Juli 2019.

Populasi dalam penelitian ini adalah anak dan ibu tunggal se-Kecamatan Rumbai kota Pekanbaru. Teknik sampel yang digunakan yaitu sampel jenuh dengan jumlah 22 anak dan ibu tunggal.

Teknik analisi data yang digunakan untuk menguji hipotesis ini adalah analisi korelasi Chi Squre yang digunakan untuk mengetahui pengaruh antara regulasi emosi single mother (variabel bebas) terhadap penerimaan diri anak (variabel terikat).

$$
\mathrm{X}^{2}=\sum \frac{(f o-f h) 2}{f h}
$$




\section{HASIL DAN PEMBAHASAN}

\section{Hasil}

Sebaran secara keseluruhan dari skor harga diri disajikan dalam daftar skor aspek Regulasi Emosi Single Mother. Untuk lebih jelasnya dapat dilihat pada tabel berikut:

Tabel 1. Skor Aspek Variabel Regulasi Emosi Single Mother

\begin{tabular}{|c|c|c|c|c|c|c|c|}
\hline No & Indikator & $\begin{array}{l}\text { Jumlah } \\
\text { Item }\end{array}$ & $\begin{array}{c}\text { Skor } \\
\text { Faktual }\end{array}$ & $\begin{array}{l}\text { Skor } \\
\text { Ideal }\end{array}$ & $\begin{array}{l}\text { Rata- } \\
\text { rata }\end{array}$ & $\begin{array}{c}\text { Persentase } \\
(\%)\end{array}$ & Kategori \\
\hline 1 & $\begin{array}{l}\text { Kendali diri, dalam arti } \\
\text { mampu mengelola } \\
\text { emosi dan implus yang } \\
\text { merusak dengan efektif. }\end{array}$ & 4 & 312 & 440 & 3,55 & $70,91 \%$ & Baik \\
\hline 2 & $\begin{array}{l}\text { Memiliki hubungan } \\
\text { interpersonal yang baik } \\
\text { dengan orang lain. }\end{array}$ & 3 & 253 & 330 & 3,83 & $76,67 \%$ & Baik \\
\hline 3 & Memiliki sikap hati-hati. & 5 & 397 & 550 & 3,61 & $72,18 \%$ & Baik \\
\hline 4 & $\begin{array}{l}\text { Memiliki adaptibilitas } \\
\text { yang artinya luwes } \\
\text { dalam menangani } \\
\text { perubahan dan } \\
\text { tantangan. }\end{array}$ & 4 & 308 & 440 & 3,50 & $70,00 \%$ & Baik \\
\hline 5 & $\begin{array}{l}\text { Toleransi yang tinggi } \\
\text { terhadap frustasi. }\end{array}$ & 4 & 300 & 440 & 3,41 & $68,18 \%$ & Baik \\
\hline \multirow[t]{3}{*}{6} & $\begin{array}{l}\text { Memiliki pandangan } \\
\text { positif terhadap diri dan } \\
\text { lingkungan. }\end{array}$ & 5 & 402 & 550 & 3,65 & $73,09 \%$ & Baik \\
\hline & Total & 25 & 1.972 & 2.750 & 21,55 & $431,03 \%$ & \multirow{2}{*}{ Baik } \\
\hline & Rata-rata & & & & & $71,83 \%$ & \\
\hline
\end{tabular}

Dari tabel diatas menunjukkan jumlah skor pada Regulasi Emosi Single Mother dapat diketahui skor pada indikator 1 sebesar 312 atau 70,91\% dari yang diharapkan, skor pada indikator 2 sebesar 253 atau 76,67\% dari yang diharapkan, skor pada indikator 3 sebesar 397 atau 72,18\% dari yang diharapkan, skor pada indikator 4 sebesar 308 atau 70,00\% dari yang diharapkan, skor pada indikator 5 sebesa 300 atau 68,18\% dari yang diharapkan,dan skor pada indikator 6 sebesar 402 atau 73,09\% dari yang diharapkan. Jadi dapat dilihat secara deskriptif bahwa skor tertinggi pada 
gambaran Regulasi Emosi Single Mother yaitu pada indikator 2 memiliki hubungan interpersonal yang baik dengan orang lain, bernilai 253 dengan persentase 76.67\%, hal ini dalam arti single mother memiliki hubunganyang baik dengan orang lain, serta peka terhadap perasaan orang lain. Sedangkan skor terendah didapatkan pada indikator 5 Toleransi yang tinggi terhadap frustasi, dengan skor 300 dengan persentase $68,18 \%$, ini berartikan bahwa rendahnya kemampuan seorang single mother dalam menyelesaikan masalah, serta keadaan mudah putus asa. Dilihat dari rata-rata empirik yang dihasilkan oleh keseluruhan subjek yaitu sebesar 68.818 maka dapat diketahui bahwa Regulasi Emosi Single Mother berada dalam kategori sedang. Untuk memperkuat hasil penelitian yang telah diteliti oleh penulis, maka penulis menambahkan penelitian yang telah dilakukan oleh Barbara D.R. Wangge (2013), penelitian ini bertujuan untuk mengetahui hubungan antara penerimaan diri dengan harga diri pada remaja pasca perceraian orangtua. Penelitian dilakukan di SMAK St.Maria Surabaya dan beberapa subjek yang didata secara pribadi. Penelitian ini bersifat kuantitatif dengan alat pengumpul data berupa kuesioner penerimaan diri dan harga diri pada remaja. Validitas isi alat ukur didapatkan dari penilaian profesional dan dosen Fakultas Psikologi Universitas Airlangga Surabaya, serta melalui uji seleksi aitem. Reliabilitas alat ukur skala penerimaan diri dan harga diri pada remaja pasca perceraian orangtua yaitu sebesar 0,814 untuk skala penerimaan diri, dan 0,912 untuk skala harga diri. Analisis data dilakukan dengan teknik analisis statistik parametrik dengan bantuan program statistik SPSS versi 16.0. Berdasarkan hasil analisa penelitian, diperoleh hasil bahwa semakin tinggi penerimaan diri maka semakin tinggi pula harga diri pada remaja pasca perceraian orangtua. Penelitian yang telah dilakukan oleh Barbara memiliki kesamaan dengan penelitian yang telah dilakukan oleh penulis, yaitu seseorang mampu menerima dirinya dengan baik apabila mendapatkan perlakuan yang baik pula.

Agar skor pada penelitian ini dapat memberikan gambaran yang jelas, maka dibuat tiga kategori kelompok regulasi emosi single mother penelitian sebagai berikut:

Tabel 2. Kategori Skor Variabel Regulasi Emosi Single Mother

\begin{tabular}{cccc}
\hline Keterangan & Rentang Nilai & Frekuensi & Persentase \\
\hline Tinggi & $\mathrm{X}>91,67$ & 10 & $45,5 \%$ \\
Sedang & $58,33 \leq \mathrm{X}<91,67$ & 12 & $54,5 \%$ \\
Rendah & $\mathrm{X}<58,33$ & 0 & $0,0 \%$ \\
\hline Total & Jumlah & $\mathbf{2 2}$ & $\mathbf{1 0 0 . 0} \%$ \\
\hline
\end{tabular}


Berdasarkan perolehan data skor pada tabel di atas menunjukkan bahwa 10 single mother regulasi emosinya tinggi. Sedangkan sisanya berjumlah 12 single mother regulasi emosinya sedang, dan tidak terdapatnya regulasi emosi single mother pada kategori rendah.

Sebaran secara keseluruhan dari skor penerimaan diri anak dapat disajikan dalam daftar skor aspek variabel penerimaan diri anak. Untuk lebih jelasnya dapat dilihat pada tabel berikut:

Tabel 3. Skor Aspek Variabel Penerimaan Diri Anak

\begin{tabular}{|c|c|c|c|c|c|c|c|}
\hline No & Indikator & $\begin{array}{c}\text { Jumlah } \\
\text { Item }\end{array}$ & $\begin{array}{c}\text { Skor } \\
\text { Faktual }\end{array}$ & $\begin{array}{l}\text { Skor } \\
\text { Ideal }\end{array}$ & $\begin{array}{l}\text { Rata- } \\
\text { rata }\end{array}$ & $\begin{array}{c}\text { Persentase } \\
(\%)\end{array}$ & Kategori \\
\hline 1 & $\begin{array}{l}\text { Memberikan } \\
\text { penghargaan terhadap } \\
\text { diri sendiri, yakin dan } \\
\text { tidak terpengaruh } \\
\text { terhadap orang lain. }\end{array}$ & 3 & 171 & 198 & 2,59 & $86,36 \%$ & $\begin{array}{l}\text { Sangat } \\
\text { Baik }\end{array}$ \\
\hline 2 & $\begin{array}{l}\text { Percaya akan potensi } \\
\text { yang ia miliki serta } \\
\text { optimis. }\end{array}$ & 3 & 147 & 198 & 2,23 & $74,24 \%$ & Baik \\
\hline \multirow[t]{3}{*}{3} & $\begin{array}{l}\text { Bertanggung jawab } \\
\text { terhadap keadaan dan } \\
\text { berani menghadapi } \\
\text { resiko/tantangan. }\end{array}$ & 3 & 165 & 198 & 2,50 & $83,33 \%$ & $\begin{array}{c}\text { Sangat } \\
\text { Baik }\end{array}$ \\
\hline & Total & 9 & 483 & 594 & 7,32 & $243,93 \%$ & $\begin{array}{c}\text { Sangat } \\
\text { Baik }\end{array}$ \\
\hline & Rata-rata & & & & & $81,31 \%$ & \\
\hline
\end{tabular}

Dari tabel diatas mengenai Penerimaan Diri Pada Anak diketahui skor pada indikator 1 sebesar 198 atau 86,36 \% dari yang diharapkan, skor pada indikator 2 sebesar 147 atau 74,24\% dari yang diharapkan, skor pada indikator 3 sebesar 165 atau 83,33\%. Jadi indikator Penerimaan Diri Pada Anak yang tertinggi adalah indikator 1 yaitu memberikan penghargan terhadap diri sendiri, yakin dan tidak terpengaruh terhadap orang lain dengan nilai 86,36\% dalam kategori sangat baik, hal ini berarti bahwa anak mampu menerima posisinya sebagai anak dari single mother dengan hati terbuka serta percaya diri dan tidak mudah terpengaruh oleh orang lain, kemudian didapatkan indikator terendah yaitu pada indikator 2 percaya akan potensi yang ia miliki serta optimis dengan nilai 74,24\% dalam kategori baik, hal ini berarti bahwa anak memiliki pandangan yang baik terhadap dirinya sendiri serta mampu mengembangkan minat dan bakat yang ia miliki. Dari tabel 
diatas juga diketahui bahwa rata-rata dari persentase keseluruhan nilai Penerimaan Diri Pada Anak sebesar 81,31\% dengan kategori sangat baik. Untuk memperkuat hasil penelitian mengenai regulasi emosi single mother maka penulis menambahkan penelitian yang telah dilakukan oleh Anindya Ikasari (2017) juga melakukan penelitian yang bertujuan untuk mengetahui hubungan antara regulasi emosi dengan stres pengasuhan ibu yang memiliki anak cerebral palsy. Pengumpulan data menggunakan dua skala likert yaitu skala stres pengasuhan (37 aitem, $\alpha=0,941)$ dan skala regulasi emosi (37 aitem, $\alpha$ $=0,972)$ Hasil analisis data dengan menggunakan analisis regresi linier sederhana menunjukkan adanya hubungan negatif antara variabel regulasi emosi dengan stres pengasuhan ibu dengan anak cerebral palsy $(\mathrm{r}=-0,451, \mathrm{p}=0,001)$. Hal ini menunjukan bahwa semakin tinggi tingkat regulasi emosi, maka semakin rendah tingkat stres pengasuhan ibu dan sebaliknya.

Agar skor pada penelitian ini dapat memberikan gambaran yang jelas, maka dibuat tiga kategori kelompok Penerimaan Diri Anak subjek penelitian sebagai berikut:

Tabel 4. Kategori Skor Variabel Penerimaan Diri Anak

\begin{tabular}{llll}
\hline Keterangan & Rentang Nilai & Frekuensi & Persentase \\
\hline Tinggi & $\mathrm{X}>21$ & 18 & $81,8 \%$ \\
Sedang & $15 \leq \mathrm{X}<21$ & 4 & $18,2 \%$ \\
Rendah & $\mathrm{X}<15$ & 9 & $0,0 \%$ \\
\hline & Jumlah & $\mathbf{2 2}$ & $\mathbf{1 0 0 . 0} \%$
\end{tabular}

Tabel diatas menunjukkan bahwa 18 anak memiliki penerimaan diri yang tinggi, 4 anak berada pada kategori sedang, dan sisanya 9 anak memiliki penerimaan diri yang rendah.

\section{Uji Prasyarat:}

\section{a. Uji Normalitas}

Uji normalitas variabel harga diri dengan komunikasi interpersonal guru dilakukan uji Kolomogrov-Smirnov dengan program SPSS (Statistics Pragrame Society Science) versi 25 for window berupa test of normality seperti terlihat pada gambar dibawah ini : 
Tabel 5. Hasil Uji Normalitas

\begin{tabular}{|c|c|c|c|}
\hline \multicolumn{4}{|c|}{ One-Sample Kolmogorov-Smirnov Test } \\
\hline & & Regulasi Emosi & Penerimaan Diri \\
\hline$N$ & & 22 & 22 \\
\hline \multirow[t]{2}{*}{ Normal Parameters ${ }^{a, b}$} & Mean & 68.8182 & 21.9545 \\
\hline & Std. Deviation & 3.00216 & 2.31922 \\
\hline \multirow[t]{3}{*}{ Most Extreme Differences } & Absolute & .158 & .160 \\
\hline & Positive & .158 & .160 \\
\hline & Negative & -.120 & -.159 \\
\hline Test Statistic & & .158 & .160 \\
\hline Asymp. Sig. (2-tailed) & & $.164^{c}$ & $.150^{c}$ \\
\hline \multicolumn{4}{|c|}{$\begin{array}{l}\text { a. Test distribution is Normal. } \\
\text { b. Calculated from data. } \\
\text { c. Lilliefors Significance Correction. }\end{array}$} \\
\hline
\end{tabular}

Dari hasil uji normalitas Kolmogorov-smirnov di atas didapat bahwa data kedua variabel tersebut dalam distribusi datanya adalah memiliki signifikan $>0,05$. Untuk variabel Regulasi Emosi Single Mother mempunyai signifikan 0,164 >0,05 dan untuk variabel Penerimaan Diri Pada Anak memiliki signifikan 0,150 > 0,05. Dapat disimpulkan bahwa untuk variabel terikat yaitu Penerimaan Diri Pada Anak $(\mathrm{Y})$ dan variabel bebes regulasi emosi single mother $(\mathrm{X})$ berasal dari populasi normal pada taraf signifikansi 0,05, maka variabel secara statistik telah berdistribusi secara normal dan layak digunakan sebagai data penelitian.

\section{b. Uji Linieritas}

Uji linieritas dilakukan untuk mengetahui bentuk hubungan antara variabel bebas yaitu regulasi emosi single mother $(\mathrm{X})$ dan variabel terikat yaitu Penerimaan diri pada anak $(\mathrm{Y})$. Pengujian linieritas menggunakan SPSS. Pengujian ini dilakukan untuk menentukan analisis antara variabel seperti yang terdapat pada tabel berikut:

Tabel 6. Hasil Uji Linieritas

\begin{tabular}{|c|c|c|c|c|c|c|c|}
\hline \multicolumn{8}{|c|}{ ANOVA Table } \\
\hline & & & Sum of Squares & $D f$ & Mean Square & $F$ & Sig. \\
\hline \multirow{6}{*}{$\begin{array}{l}\text { Penerimaa } \\
\text { n Diri * } \\
\text { Regulasi } \\
\text { Emosi }\end{array}$} & Between & (Combined) & 97.755 & 12 & 8.146 & 4.823 & .012 \\
\hline & Groups & Linearity & 51.592 & 1 & 51.592 & 30.548 & .000 \\
\hline & & Deviation from & 46.162 & 11 & 4.197 & 2.485 & .091 \\
\hline & & Linearity & & & & & \\
\hline & Within & roups & 15.200 & 9 & 1.689 & & \\
\hline & Total & & 112.955 & 21 & & & \\
\hline
\end{tabular}


Berdasar kan tabel di atas, analisis data menghasilkan nilai F 30,548 dengan signifikansi linierity 0,000, karena $\mathrm{P}<0,05$ dengan nilai signifikansi variabel bernilai 5\% atau 0,05, akan dapat disimpulkan bahwa garis antara regulasi emosi single mother terhadap penerimaan diri pada anak Sekecamatan Rumbai kota Pekanbaru mempunyai hubungan linier. Karena hasil analisis menunjukkan bahwa Sig 0,000 < 0,05, sehingga dapat dikatan bahwa hubungan kedua variabel tersebut adalah linier.

\section{c. Uji Homogeitas}

Pengujian homogenitas dimaksudkan untuk memberikan keyakinan bahwa sekumpulan data yang dimanipulasi dalam serangkaian analisis memang berasal dari populasi yang tidak jauh berbeda keragamannya Kolom yang dilihat pada print out ialah kolom Sig, jika nilai pada kolom Sig. $>0,05$ maka Ho diterima.

\section{Tabel 7. Hasil Uji Homogenitas}

\begin{tabular}{|c|c|c|}
\hline \multicolumn{3}{|c|}{ Test Statistics } \\
\hline & Regulasi Emosi & Penerimaan Diri \\
\hline Chi-Square & $12,273^{a}$ & $11,545^{b}$ \\
\hline$D f$ & 12 & 8 \\
\hline Asymp. Sig. & ,424 &, 173 \\
\hline $\begin{array}{l}\text { a. } 13 \text { cells }(1 \\
\text { b. } 9 \text { cells }(10\end{array}$ & $\begin{array}{l}\text { cies less than } 5 \text {. The minimun } \\
\text { ies less than 5. The minimum }\end{array}$ & $\begin{array}{l}\text { ted cell frequency is } 1,7 \\
d \text { cell frequency is } 2,4 \text {. }\end{array}$ \\
\hline
\end{tabular}

Tabel 8. Hasil Pengujian Hipotesis Regulasi Emosi Single Mother terhadap Penerimaan Diri Anak

\begin{tabular}{|c|c|c|c|c|c|c|}
\hline \multirow{2}{*}{ No } & \multirow{2}{*}{$\begin{array}{c}\text { Regulasi } \\
\text { Emosi }\end{array}$} & \multicolumn{3}{|c|}{ Penerimaan Diri } & \multirow{2}{*}{ Jumlah } & \multirow{2}{*}{ Sig } \\
\hline & & Baik & Cukup & Kurang & & \\
\hline 1 & Tinggi & $\begin{array}{l}10 \\
(100 \%)\end{array}$ & $\begin{array}{l}0 \\
(0 \%)\end{array}$ & $\begin{array}{l}0 \\
(0 \%)\end{array}$ & $10(100 \%)$ & \multirow{4}{*}{0,044} \\
\hline 2 & Sedang & $8(66,7 \%)$ & $4(33,3 \%)$ & $\begin{array}{l}0 \\
(100 \%)\end{array}$ & $12(100 \%)$ & \\
\hline \multirow[t]{2}{*}{3} & Rendah & $\begin{array}{l}0 \\
(0 \%)\end{array}$ & $\begin{array}{l}0 \\
(0 \%)\end{array}$ & $\begin{array}{l}0 \\
(0 \%)\end{array}$ & $\begin{array}{l}0 \\
(0 \%)\end{array}$ & \\
\hline & Jumlah & $\begin{array}{l}18 \\
(81,8 \%)\end{array}$ & $4(18,2 \%)$ & $\begin{array}{l}0 \\
(0,00 \%)\end{array}$ & 73 & \\
\hline
\end{tabular}

Berdasarkan hasil di atas, menunjukan bahwa responden dengan regulasi emosi tinggi seluruhnya memiliki penerimaan diri baik 100\% dan regulasi emosi sedang mayoritas memiliki penerimaan diri baik 66,7\% lebih banyak dibandingkan cukup 33,3\% . 
Berdasarkan hasil perhitungan chi square diperoleh nilai sig $<0,05$ (sig $=0,044$ ) sehingga dapat diartikan bahwa ada pengaruh signifikan antara regulasi emosi single mother terhadap penerimaan diri pada anak. Artinya semakin tinggi regulasi emosi single mother maka penerimaan diri pada anak akan semakin baik, dan sebaliknya semakin rendah regulasi emosi single mother maka penerimaan diri pada anak akan semakin rendah atau berkurang.

\section{Pembahasan}

Mengenai gambaran penerimaan diri pada anak se-kecamatan rumbai kota pekanbaru, didapatkan skor tertinggi pada indikator 1 yaitu memberikan penghargan terhadap diri sendiri, yakin dan tidak terpengaruh terhadap orang lain dengan persentase 86,36\% dalam kategori sangat baik. Hal ini dikarenakan anak mampu menerima posisinya sebagai anak dari single mother dengan hati terbuka, percaya diri dan tidak mudah terpengaruh oleh pendapat teman-temannya yang lain, serta anak mampu menilai secara realitas keadaan yang sedang dialaminya. Kemudian didapatkan skor terendah yaitu pada indikator 2 percaya akan potensi yang ia memiliki serta optimis, dengan persentase $74,24 \%$ dalam kategori baik. Dalam arti rendahnya pandangan yang baik anak terhadap dirinya sendiri, kurangnya kemampuan anak dalam mengembangkan minat dan bakat yang anak miliki, serta anak mudah menyalahkan orang lain dan menganggap bahwa ia berbeda dengan teman lainnya yang memiliki keluarga utuh. Kemudia didapatkan rata-rata dari hasil keseluruhan penerimaan diri anak sebesar 81,31\%. Dilihat dari rata-rata empirik yang dihasilkan oleh keseluruhan subjek yaitu sebesar 21,954 maka dapat diketahui penerimaan diri pada berada dalam kategori tinggi. Temuan penelitian ini memiliki kesamaan dengan penelitian yang telah dilakukan oleh Ria Novianti (2018). Ria dalam jurnalnya menyatakan bahwa secara umum peran orangtua dalam menumbuhkan resiliensi anak adalah mutlak terutama pada anak usia dini, hal ini dikarenakan pada anak usia dini diintervensi lingkungan luar terhadap anak masih minimal dan orangtua lah yang memiliki pengaruh terhadap perkembangan anak, sedangkan temuan dalam penelitian ini menemukan bahwa anak yang berada pada posisi anak dari single mother sangat membutuhkan peran orangtua agar ia dapat menerima posisi dirinya dengan baik.

Dalam jurnal Gharnish (2015) menyatakan bahwa seseorang yang menerima diri diartikan sebagai individu yang tidak bermasalah dengan diri sendiri, sehingga memiliki kesempatan untuk bergaul dengan lingkungan sekitarnya. Seseorang yang mampu menerima dirinya, menilai kelebihan dan kekurangan diri secara objektif akan memiliki harga diri yang baik. Dari hasil penelitiannya, 
maka didapatkan bahwa (1) Penerimaan diri pada remaja di Panti Asuhan Yatim Putri Aisyiyah di Yogyakarta berada pada kategori sedang atau cukup, (2) Harga diri pada remaja di Panti Asuhan Yatim Putri Aisyiyah di Yogyakarta berada pada kategori sedang atau cukup, (3) Ada pengaruh positif dan signifikan variabel penerimaan diri terhadap harga diri dengan nilai $\mathrm{p}(0,000)>0,05$. Selanjutmya Dina Yulia Sudhar (2010) menulis dalam jurnalnya mengenai penerimaan diri dengan kompetensi interpersonal pada remaja panti asuhan. Penelitian ini bertujuan untuk mengetahui hubungan antara penerimaan diri dengan kompetensi interpersonal pada remaja panti asuhan. Hipotesis yang diajukan ada hubungan antara penerimaan diri dengan kompetensi interpersonal pada remaja panti asuhan. Subjek penelitian remaja Panti Asuhan Anak Keluarga yatim Muhammadiyah Surakarta. Adapun jumlah sampel keseluruhan yaitu 48 orang. Metode pengumpulan data menggunakan skala penerimaan diri dan skala kompetensi interpersonal. Teknik analisis data menggunakan korelasi product moment. Berdasarkan hasil perhitungan teknik analisis product moment dari Pearson diperoleh nilai koefisien korelasi ( $\mathrm{r}$ ) sebesar 0,$391 ; \mathrm{p}=0,003(\mathrm{p}<0,01)$ artinya ada hubungan positif yang sangat signifikan antara penerimaan diri dengan kompetensi interpersonal. Semakin tinggi (kuat) penerimaan diri seseorang maka semakin tinggi pula kompetensi interpersonalnya sebaliknya semakin rendah penerimaan diri maka semakin rendah pula kompetensi interpersonalnya. Berdasarkan hasil analisis diketahui variabel penerimaan diri mempunyai rerata empirik (RE) sebesar 136,15 dan rerata hipotetik (RH) sebesar 105 yang berarti penerimaan diri pada subjek tergolong tinggi. Variabel kompetensi interpersonal diketahui rata-rata empirik (RE) sebesar 101,10 dan rata-rata hipotetik (RH) sebesar 82,5 yang berarti kompetensi interpersonal pada subjek penelitian tergolong tinggi. Selanjutnya penulis juga menambahkan jurnal pembanding lainnya, yaitu Novita Dwi Aryani (2015), tujuan dilakukannya penelitian ini untuk mengetahui pengaruh hubungan orang tua anak dan penerimaan diri terhadap keputusasaan pada remaja. Penelitian melibatkan 150 remaja dari keluarga broken home. Pengambilan data menggunakan instrumen Parent Child Relationship Scale, Unconditional Self Acceptance Questionnaire, dan Beck Hopelessness Scale (BHS). Uji signifikansi memperlihatkan F hitung 36.708 (sig. 0,000<0,05), artinya terdapat pengaruh hubungan orangtua anak dan penerimaan diri terhadap keputusasaan remaja. Model ini signifikan dan dapat digunakan memprediksi keputusasaan melalui hubungan orang tua anak dan penerimaan diri sebagai moderator. Hasil penelitian menunjukkan bahwa keputusasaan pada remaja dari keluarga broken home dapat dijelaskan secara bersama-sama antara hubungan orang tua anak sebagai variabel independen dan penerimaan diri sebagai moderator sebesar 41,8\%. Penelitian Intan 
mengenai penerimaan diri remaja dari keluarga broken home, berkaitan dengan penelitian yang telah dilakukan oleh Tamasari, Galuh (2019) mengenai penerimaan diri remaja terhadap perceraian orangtua yang mana pada penelitian ini bertujuan untuk mengetahui dan memperoleh pemahaman secara komprehensif mengenai gambaran penerimaan diri pada remaja yang orang tuanya bercerai dan faktor-faktor yang mempengaruhinya. Metode dalam penelitian ini menggunakan metode kualitatif, yang bertujuan untuk memperoleh pemahaman yang menyeluruh dan mengenai topik atau judul yang diteliti menggunakan metode pengambilan data yaitu wawancara. Hasil penelitian menunjukkan bahwa gambaran penerimaan diri pada remaja yang orang tuanya bercerai melalui aspek kerelaan yaitu perceraian orang tua dianggap sebagai kekurangan namun tidak dijadikan beban justru di jadikan motivasi diri. Subjek menerima perceraian orang tua dengan berpikir dewasa, subjek mampu bersikap terbuka terhadap orang lain. Subjek sangat selektif menceritakan privasi dengan orang yang memiliki kedekatan khusus subjek mampu menerima keputusan perceraian orang tua dan kondisi orang tua saat ini menerima perbedaan interaksi dengan orang tua setelah perceraian terjadi. Aspek kesehatan psikologis terlihat pada sikap saling memberikan dukungan antar anggota keluarga dalam berbagai kesempatan. Subjek penelitian merasa bahagia dengan kondisi keluarga saat ini. Aspek penerimaan terhadap orang lain menunjukkan bahwa subjek merasa diterima oleh lingkungan sehingga dapat bergaul dengan baik dan bersikap terbuka dalam pergaulan dan memiliki banyak komunitas. Penelitian yang telah dilakukan oleh Novita dan Tamasari memiliki kaitan dengan penelitian yang telah dilakukan oleh Barbara D.R. Wangge (2013), penelitian ini bertujuan untuk mengetahui hubungan antara penerimaan diri dengan harga diri pada remaja pasca perceraian orangtua. Penelitian dilakukan di SMAK St.Maria Surabaya dan beberapa subjek yang didata secara pribadi. Penelitian ini bersifat kuantitatif dengan alat pengumpul data berupa kuesioner penerimaan diri dan harga diri pada remaja. Validitas isi alat ukur didapatkan dari penilaian profesional dan dosen Fakultas Psikologi Universitas Airlangga Surabaya, serta melalui uji seleksi aitem. Reliabilitas alat ukur skala penerimaan diri dan harga diri pada remaja pasca perceraian orangtua yaitu sebesar 0,814 untuk skala penerimaan diri, dan 0,912 untuk skala harga diri. Analisis data dilakukan dengan teknik analisis statistik parametrik dengan bantuan program statistik SPSS versi 16.0. Berdasarkan hasil analisa penelitian, diperoleh hasil bahwa semakin tinggi penerimaan diri maka semakin tinggi pula harga diri pada remaja pasca perceraian orangtua. Selain itu Retty Fauzia (2018) dalam penelitiannya Retty menelaah tentang peran trait mindfulness (rasa kesadaran) terhadap penerimaan diri remaja dengan orangtua bercerai di DKI Jakarta. Penelitian ini 
menggunakan pendekatan kuantitatif dengan desain asosiatif. Penelitian dilakukan dengan menggunakan adaptasi alat ukur Unconditional Self-Acceptance Questionnaire (USAQ) dan Mindful Attention Awareness Scale (MAAS). Hasil penelitian menunjukkan bahwa traitmind fullness (rasa kesadaran) berperan signifikan dengan kontribusi efektif sebesar 17,4\%. Peran rasa kesadaran terhadap penerimaan diri bersifat positif, yang artinya peningkatan rasa kesadaran berperan terhadap peningkatan penerimaan diri dari pada remaja dengan orangtua bercerai. Hal ini mengindikasikan pentingnya memberi perhatian kepada rasa kesadaran dalam pengembangan penerimaan diri pada remaja dengan orangtua becerai.

Dari keenam jurnal di atas maka dapat disimpulkan bahwa Garnish (2015) menyatakan adanya pengaruh positif dan signifikan variabel penerimaan diri terhadap harga diri dengan nilai $\mathrm{p}$ $(0,000)>0,05$, dan penerimaan diri remaja di Panti Asuhan Yatim Putri Aisyiyah di Yogyakarta berada pada kategori sedang atau cukup, kemudian Dina Yulia Sudhar (2010) memperoleh hasil perhitungan teknik analisis product moment daengan nilai koefisien korelasi $(\mathrm{r})$ sebesar 0,$391 ; \mathrm{p}=$ $0,003(\mathrm{p}<0,01)$ artinya ada hubungan positif yang sangat signifikan antara penerimaan diri dengan kompetensi interpersonal, dalam arti semakin tinggi (kuat) penerimaan diri seseorang maka semakin tinggi pula kompetensi interpersonalnya sebaliknya semakin rendah penerimaan diri maka semakin rendah pula kompetensi interpersonalnya. Novita Dwi Arynai (2015) yang mana hasil uji signifikansi memperlihatkan F hitung 36.708 (sig. 0,000<0,05), artinya terdapat pengaruh hubungan orangtua anak dan penerimaan diri terhadap keputusasaan remaja Selanjutnya penelitian oleh Tamasari, Galuh (2019) dari pengambilan data yang dilakukannya hasil penelitian menunjukkan bahwa gambaran penerimaan diri pada remaja yang orang tuanya bercerai melalui aspek kerelaan yaitu perceraian orang tua dianggap sebagai kekurangan namun tidak dijadikan beban justru di jadikan motivasi diri, yang mana memiliki kesamaan dengan Retty Fauzia (2018) dalam penelitiannya Retty menelaah tentang peran trait mindfulness (rasa kesadaran) terhadap penerimaan diri remaja dengan orangtua bercerai di DKI Jakarta. Hasil penelitian menunjukkan bahwa peran rasa kesadaran terhadap penerimaan diri bersifat positif, yang artinya peningkatan rasa kesadaran berperan terhadap peningkatan penerimaan diri dari pada remaja dengan orangtua bercerai. Hal ini mengindikasikan pentingnya memberi perhatian kepada rasa kesadaran dalam pengembangan penerimaan diri pada remaja dengan orangtua becerai. Selain itu Barbara D.R. Wangge (2013) dalam 
penelitiannya memperoleh hasil analisa penelitian yaitu semakin tinggi penerimaan diri maka semakin tinggi pula harga diri pada remaja pasca perceraian orangtua.

Selanjutnya penulis menambahkan jurnal yang telah diteliti oleh penulis lainnya guna untuk memperkuat hasil yang telah diteliti oleh penulis. Intan Megasari (2016), dalam jurnalnya bertujuan untuk mengetahui hubungan antara dukungan sosial suami dengan penerimaan diri pada ibu yang memiliki anak down syndrome. Pada ibu dengan anak down syndrome, adanya bentuk perilaku ibu yang menarik diri dari interaksi sosial, menyalahkan diri atas setiap peristiwa yang dialami dan menunjukan pelampiasan emosi negatif terhadap anak akan sangat berpengaruh pada proses perawatan anaknya, untuk itu dukungan sosial suami yang diberikan kepada ibu sangatlah penting dalam meningkatkan penerimaan diri pada ibu. Subjek penelitian ini adalah 51 ibu dengan anak down syndrome di beberapa SLB di Semarang. Teknik pengambilan sampel menggunakan cluster random sampling. Instrument penelitian terdiri dari dua skala yaitu Skala Penerimaan Diri Ibu (21 aitem ; $\alpha=0,825$; rix $=0,25$ ) dan Skala Dukungan Sosial Suami (31 aitem $\alpha$ sebesar 0,933 dengan rix $=0,30)$. Hasil penelitian menunjukan bahwa ada hubungan positif antara dukungan sosial suami dengan penerimaan diri pada ibu yang memiliki anak down syndrome $(r=0,704)$, dimana dukungan sosial suami memberikan sumbangan sebesar 49,5\%. Penelitian yang telah dilakukan oleh Intan memiliki kesamaan dengan Retno Twistiandayani (2015), Desain penelitian ini menggunakan Cross sectional design, dengan total sampling. Sampel yang diambil sebanyak 40 responden. Variabel independennya adalah dukungan keluarga dan variabel dependennya adalah penerimaan diri ibu. Data penelitian ini diambil dengan menggunakan kuisioner. Dari hasil uji statistik Mann Whitney didapatkan hasil $\left(\alpha_{\text {hitung }}\right)=0,000$ artinya ada hubungan kuat antara dukungan keluarga dengan penerimaan diri ibu yang memiliki anak autis. Dukungan keluarga terhadap ibu yang memiliki anak autis merupakan landasan utama ibu dalam merawat anaknya dengan baik. Selain penerimaan diri dari seorang ibu, penulis juga mencantumkan penerimaan diri oleh remaja, dalam jurnal Wenny Aidina (2013), bertujuan untuk mengetahui hubungan antara penerimaan diri dengan optimisme menghadapi masa depan pada remaja di panti asuhan. Pengumpulan data dilakukan dengan menggunakan skala penerimaan diri yang disusun berdasarkan pada teori yang dikemukakan oleh Sheerer dan skala optimisme menghadapi masa depan yang mengacu pada teori Seligman. Hasil analisis data menggunakan teknik korelasi Spearman menunjukkan koefisien korelasi (r) sebesar 0,398 dengan nilaip $=0,002(\mathrm{p}<0,05)$. Hal ini dapat diartikan bahwa terdapat hubungan positif antara penerimaan diri dengan optimisme menghadapi masa depan pada remaja dipanti asuhan. Jadi 
kesimpulannya semakin tinggi penerimaan diri maka semakin tinggi optimisme menghadapi masa depan atau sebaliknya. Membahas tentang remaja, penulis juga menambahkan penelitian yang telah dilakukan oleh Devina juwita sari (2013) penelitian ini bertujuan untuk mengetahui hubungan yang signifikan antar dukungan sosial dengan penerimaan diri remaja penderita HIV di Surabaya. Rancangan penelitian yang digunakan adalah korelasional. Subjek pada penelitian ini adalah remaja Yayasan Orbit Surabaya yang terkena HIV karena penggunaan Narkoba, yang berjumlah 30 remaja. Hipotesis pada penelitian ini adalah terdapat hubungan dukungan sosial dengan penerimaan diri remaja penderita HIV. Teknik analisis yang digunakan adalah teknik analisis korelasi product moment dari Carl Pearson. Hasil analisis data diperoleh nilai r sebesar 0,664 dan $\mathrm{p}=0,000(\mathrm{p}<0,05)$ sehingga hipotesis penelitian diterima. Ini menunjukkan bahwa ada hubungan positif yang signifikan antara dukungan sosial dengan penerimaan diri remaja penderita HIV di Surabaya. Artinya semakin tinggi dukungan sosial maka semakin tinggi pula penerimaan diri, dan begitu juga sebaliknya. Semakin rendah dukungan sosial, maka semakin rendah penerimaan diri.

Dalam hal ini anak mampu menerima dirinya dengan baik, diawali dengan kemampuan seorang ibu yang meregulasikan emosinya dengan baik pula. Regulasi emosi yang dimiliki seorang single mother akan berpengaruh terhadap penerimaan diri pada anak, jika seseorang memiliki regulasi emosi baik maka dapat dilihat dari diri seseorang mengenai keterampilan mengenal emosi, keterampilan mengekspresikan emosi, keterampilan mengelola emosi. Hal ini berkaitan dengan bagaimana single mother mengatur perannya sebagai ayah dan ibu bagi anak-anaknya, maka dibutuhkan regulasi emosi dalam mengontrol emosi single mother tersebut. Untuk memperkuat penelitan yang telah dilakukan oleh penulis, maka penulis menambahkan jurnal yang telah diteliti oleh penulis lainnya. Sehubungan dengan pentingnya peran orangtua dalam mengasuh anaknya, maka penulis menambahkan jurnal peran orangtua dalam perkembangan kemampuan regulasi emosi anak yang diteliti oleh Wiwien Dinar Pratisti (2013) yang mana dalam peneliannya ia menyatakan bahwa regulasi emosi merupakan kemampuan untuk mengenali, mempertahankan, mengelola kemudian memilih ekspresi emosi yang paling sesuai dengan situasi di sekitarnya. Kemampuan regulasi emosi bukan hanya ditentukan oleh kondisi internal individu melainkan dipengaruhi oleh lingkungan sosialdi sekitarnya. Lingkungan yang pertama dan utama bagi individu adalah keluarga. Keluarga terdiri atas ibu dan ayah dan saudara kandung, meskipun peran utama dipegang oleh ibu dan ayah. Tulisan ini berusaha memaparkan suatu model teoritis tentang peran orangtua dalam perkembangan kemampuan regulasi emosi anak dengan melakukan telaah jurnal 
dan hasil penelitian yang telah dilakukan sebelumnya. Berbagai penelitian telah dilakukan yang hasilnya menunjukkan bahwa peran orangtuadi dalam mengembangkan kemampuan regulasi emosi dapat dibedakan menjadi tiga hal, yaitu sebagai model, pendidik dan penyedia atau pencipta iklim emosional.

Seorang single mother sangat membutuhkan regulasi emosi yang baik, guna untuk memperbaki keadaan dimasa sekarang dan yang akan datang, berkaitan dengan jurnal yang diteliti oleh Tyas Diana Uswatun Hasanah (2014), dalam jurnalnya yang berjudul regulasi emosi pada ibu single parent, yang bertujuan untuk mengetahui proses regulasi emosi dan faktor-faktor yang mempengaruhi penggunaan regulasi emosi sebagai akibat dari peristiwa yang menimbulkan emosi. Proses regulasi emosi yang digunakan subjek antara lain pemilihan situasi, perubahan situasi, penyebaran perhatian, perubahan, perubahan respon. Hasil penelitian menunjukkan ibu single parent mengalami berbagai macam emosi antara lain emosi negatif seperti depresi, stress, berdiam diri, menangis, sedih, dan marah yang ditekan, selain itu juga merasakan emosi positif seperti sabar, ikhlas, menerima, pasrah, bahagia dengan melihat anak bahagia. Jadi, kesimpulannya yaitu kemampuan regulasi emosi setiap individu berbeda-beda dipengaruhi oleh perbedaan individu, kognitif, stressor, keadaan sebelum suami meninggal, lingkungan sosial dan keluarga, religiusitas. Sehubungan dengan regulasi emosi pada seorang ibu Anindya Ikasari (2017) juga melakukan penelitian yang bertujuan untuk mengetahui hubungan antara regulasi emosi dengan stres pengasuhan ibu yang memiliki anak cerebral palsy. Pengumpulan data menggunakan dua skala likert yaitu skala stres pengasuhan (37 aitem, $\alpha=0,941)$ dan skala regulasi emosi (37 aitem, $\alpha=0,972)$ Hasil analisis data dengan menggunakan analisis regresi linier sederhana menunjukkan adanya hubungan negatif antara variabel regulasi emosi dengan stres pengasuhan ibu dengan anak cerebral palsy $(\mathrm{r}=-0,451, \mathrm{p}=$ 0,001). Hal ini menunjukan bahwa semakin tinggi tingkat regulasi emosi, maka semakin rendah tingkat stres pengasuhan ibu dan sebaliknya. Penelitian yang dilakukan oleh Anindya memiliki kesamaan dengan Rofatina, dkk (2016), yang membahas mengenai regulasi emosi ibu yang memiliki anak dengan keterbelakangan mental, dalam jurnalnya ia menyatakan bahwa regulasi emosi dan religiusitas akan memudahkan individu menyelesaikan masalah sehingga meningkatkan resiliensi, dengan tujuan penelitian untuk mengetahui: (1) Hubungan antara regulasi emosi dan religiusitas dengan resiliensi, (2) Hubungan antara regulasi emosi dengan dengan resiliensi, dan (3) Hubungan antara religiusitas dengan resiliensi. Penelitian ini merupakan penelitian populasi pada ibu yang 
memiliki anak tunagrahita di SLB-C YPSLB Kerten Surakarta yang berjumlah 32 orang. Hasil analisis regresi berganda menunjukkan nilai $\mathrm{p}=0,000(\mathrm{p}<0,05)$ dan Fhitung $=10,831>$ Ftabel $=$ 3,33. Hasil tersebut menunjukkan bahwa ada hubungan yang signifikan antara regulasi emosi dan religiusitas dengan resiliensi. Hasil analisis korelasi parsial menunjukkan bahwa ada hubungan antara regulasi emosi dengan resiliensi dengan koefisien korelasi parsial sebesar 0,564, dan $\mathrm{p}=0,000$ $(\mathrm{p}<0,05)$ serta ada hubungan antara religiusitas dengan resiliensi dengan koefisien korelasi parsial sebesar $0,754 \hat{A} \hat{A}$ dan $p=0,000(p<0,05)$. Selanjutnya mengenai regulasi emosi seorang ibu juga diteliti oleh Felayati (2017) menyatakan dalam jurnalnya tentang hubungan antara regulasi emosi dengan kekerasan ibu yang berasal dari keluarga miskin terhadap anak, yang mana Ibu sebagai figur terdekat anak berpotensi melakukan tindak kekerasan terhadap anak, terutama pada saat pengasuhan anak. Penelitian ini bertujuan untuk mengetahui hubungan antara regulasi emosi dengan kekerasan ibu terhadap anak. Sampel penelitian adalah 140 ibu yang terdaftar sebagai anggota Program Keluarga Harapan (PKH) di Kelurahan Tuah Karya. Sampel ditentukan dengan menggunakan teknik purposive sampling. Alat ukur menggunakan skala kekerasan terhadap anak dan skala regulasi emosi. Hipotesis penelitian adalah terdapat hubungan antara regulasi emosi dengan kekerasan ibu yang berasal dari keluarga miskin terhadap anak. Berdasarkan hasil analisis korelasi product moment dari Pearson's diperoleh nilai koefisien korelasi $(r=-0,476)$ dan probabilitas $(\mathrm{p}=0,000)$, artinya hipotesis diterima. Ada hubungan negatif yang signifikan antara regulasi emosi dengan kekerasan ibu terhadap anak. Hasil penelitian menunjukkan bahwa regulasi emosi dan kekerasan terhadap anak berkorelasi secara negatif. Hal ini menandakan bahwa semakin tinggi regulasi emosi ibu maka semakin rendah kekerasan ibu terhadap anak. Analisis sumbangan per aspek menunjukkan bahwa aspek modulasi respon memberi sumbangan tertinggi (Rsq=8,38\%) terhadap variabel kekerasan ibu terhadap anak.

Dari kelima jurnal diatas maka dapat ditarik kesimpulan semakin baik (tinggi) kemampuan seseorang meregulasi emosinya, maka akan menghasilkan dampak positif bagi dirinya sendiri, keluarga, teman, serta lingkungan. Selanjutnya penulis akan menambahkan jurnal dari penulis lainnya guna untuk memperkuat penelitian yang telah penulis teliti, Rully Nurmalita dan Farida Hidayati (2014) dalam penelitiannya tentang hubungan antara regulasi emosi dengan kompetensi interpersonal pada remaja panti asuhan, yang mana regulasi emosi menentukan bagaimana seseorang berperilaku sesuai situasi yang dihadapi. Regulasi emosi merupakan kemampuan individu untuk dapat mengatur emosi yang muncul dalam dirinya. Penelitian ini bertujuan untuk melihat 
hubungan antara regulasi emosi dengan kompetensi interpersonal pada remaja panti asuhan. Subjek penelitian ini adalah remaja panti asuhan di Semarang. Diambil dengan menggunakan teknik cluster sampling, sebanyak 117 remaja panti asuhan di Semarang menjadi sampel penelitian ini. Pengumpulan data menggunakan dua buah skala psikologi, yaitu skala regulasi emosi dengan 22 aitem valid $(\alpha=0,804)$ dan skala kompetensi interpersonal dengan 32 aitem valid $(\alpha=0,885)$. Analisis data dilakukan dengan menggunakan teknik analisis regresi sederhana. Hasil penelitian menunjukkan koefisien korelasi rxy $=0,662$ dengan $\mathrm{p}=0,000(\mathrm{p}<0,05)$ yang berarti hipotesis penelitian ini diterima, yaitu ada hubungan positif dan signifikan antara regulasi emosi dengan kompetensi interpersonal. Semakin tinggi regulasi emosi maka semakin tinggi pula kompetensi interpersonal dan semakin rendah regulasi emosi maka akan semakin rendah pula kompetensi interpersonal.

Selanjutnya penelitian mengenai regulasi emosi juga diteliti oleh Dini Primadewi Aris, Rinaldi. (2015) penelitian ini dilakukan untuk melihat ada atau tidaknya hubungan regulasi emosi dengan penerimaan diri wanita premenopause. Penelitian ini adalah penelitian kuantitatif. Subjek dalam penelitian ini adalah 75 ibu-ibu dengan teknik pengambilan sampel secara purposive sampling. Alat pengumpulan data dengan menggunakan skala regulasi emosi dan skala penerimaan diri. Teknik analisis data yang digunakan adalah product moment.

Berdasarkan hasil penelitian diperoleh koefisien korelasi sebesar 0.667 dengan taraf signifikansi $\mathrm{p}=0.000(\mathrm{p}<0.01)$. Hasil penelitian ini menunjukkan bahwa terdapat hubungan yang signifikan antara regulasi emosi dengan penerimaan diri wanita premenopause. Annie Aprisandityas Diana Elfida (2012) juga melakukan penelitian tentang hubungan regulasi emosi dengan kecemasan pada ibu hamil, dalam penelitiannya yang bertujuan untuk membuktikan hipotesis yang menyatakan ada hubungan antara regulasi emosi dengan kecemasan pada ibu hamil. Subjek penelitian adalah 73 orang ibu hamil yang tersebar di kota Pekanbaru. Metode pengumpulan data menggunakan skala regulasi emosi dan skala kecemasan. Data penelitian dianalisis dengan menggunakan teknik korelasi product moment yang dioperasikan dengan menggunakan bantuan program SPSS 11.5 for Windows. Hasil analisis menunjukkan koefisien korelasi antara regulasi emosi dengan kecemasan pada ibu hamil adalah -0,215 ( $\mathrm{p}=0,034)$. Hasil ini menunjukkan hipotesis yang diajukan terbukti. Dengan demikian, terdapat hubungan yang signifikan antara regulasi emosi dengan kecemasan pada ibu hamil. Semakin baik kemampuan regulasi emosi ibu hamil, maka semakin rendah kecemasan yang 
dirasakan. Penulis lainnya juga melakukan penelitian mengenai regulasi emosi oleh Fatyana Indah Permata Sari (2014), penulis bertujuan untuk mengetahui hubungan negatif antara hubungan regulasi emosi ibu dengan perilaku kecenderungan kekerasan terhadap anak di Makassar. Subjek dalam penelitian ini berjumlah 80 orang. Alat ukur yang digunakan adalah skala perilaku kekerasan orangtua terhadap anak dan skala regulasi emosi. Pengambilan sampel dilakukan dengan teknik purposive sampling. Data penelitian dianalisis dengan menggunakan teknik analisis korelasi product moment. Hasil analisis menunjukkan nilai koefisien korelasi $\mathrm{r}=-0,534$ dengan $\mathrm{p}=0,000$, hasil tersebut menunjukkan bahwa terdapat hubungan negative antara regulasi emosi ibu dengan kecenderungan perilaku kekerasan terhadap anak. Semakin tinggi regulasi emosi ibu, maka semakin rendah perilaku kekerasan terhadap anak. Jadi, dengan kemampuan seorang ibu meregulasi emosinya dengan baik, maka tidak akan terjadi kekerasan yang terjadi pada anak.

Dari jurnal yang telah dipaparkan di atas, maka penulis dapat menyimpulkan bahwa regulasi emosi sangat diperlukan bagi seseorang, dengan kemampuan meregulasi emosi dengan baik maka akan menimbulkan hal positif pula bagi keberlagsungan hidup. Kemudian, ditemukannya pengaruh regulasi emosi single mother terhadap penerimaan diri pada anak yang telah peneliti uji. Penerimaan diri pada anak dapat dilihat dari perhitungan keseluruhan indikator yaitu dengan 22 orang anak SeKecamatan Rumbai kota Pekanbaru dan didaptkan skor ideal 2.750 dengan persentase 431,03\% termasuk dalam kriteria baik. Terlihat dari jumlah keseluruhan indikator regulasi emosi single mother dapat disimpulkan bahwa regulasi emosi berada dalam kategori baik dengan persentase 71,83 \%, sedangkan pada indikator penerimaan diri anak berada dalam kategori sangat baik dengan persentase 81,31\%. Dari hasil uji Chi Square diketahuui hasil analisis diperoleh angka probabilitas sebesar 0,044 dimana 0,044 < 0,05, maka Ho ditolak dan Ha diterima. Artinya terdapat pengaruh yang signifikan antara regulasi emosi single mother terhadap penerimaan diri anak, dimana anak secara aktif melibatkan orangtuanya sebagai pedoman dan acuan dikehidupannya, sehingga jika respon yang diberikan orangtua kepada anaknya baik maka penerimaan diri pada anak dapat terlaksana dengan baik sesuai dengan harapan.

\section{SIMPULAN DAN REKOMENDASI}


Berdasarkan hasil penelitian yang telah dilakukan, dapat disimpulkan bahwa terdapat pengaruh positif antara regulasi emosi single mother terhadap penerimaan diri pada anak sekecamatan Rumbai kota Pekanbaru.

Sesuai dengan kesimpulan hasil penelitian, maka dapat dikemukakan beberapa rekomendasi, yaitu :

1. Kepada orangtua lebih banyak meluangkan waktunya untuk anak guna memberikanrasa nyaman pada anak agar anak merasa kebahagiaan dan merasa bahwa ia sama seperti anak lain nya yang juga mendapatkan kasih sayang utuh dari orangtua.

2. Kepada peneliti berikutnya diharapkan agar dapat mengembangkan penelitian mengenai Pengaruh Regulasi Emosi Single Mother terhadap Penerimaan Diri Pada Anak.

\section{REFERENSI}

Anindya Ikasari, Ika Febrian Kristiana. 2017. Hubungan Antara Regulasi Emosi Dengan Stres Pengasuban Ibu Yang Memiliki Anak Cerebral Palsy. UNDIP. Vol. 6, No. 4 (2017).

https://ejournal3.undip.ac.id/index.php/empati/article/view/20101

Annie Aprisandityas Diana Elfida. (2012) Hubungan Antara Regulasi Emosi Dengan Kecemasan Pada Ibu Hamil. Jurnal Psikologi UIN. Vol. 8, No 2, Desember 2012.

https://media.neliti.com/media/publications/126980-ID-hubungan-antara-regulasi-emosidengan-ke.pdf

Barbara D.R. Wangge, Nurul Hartini. 2013. Hubungan antara Penerimaan Diri dengan Harga Diri pada Remaja pasca Perceraian Orangtua. Fakultas Psikologi, Universitas Airlangga. Vol. 2 No. 1, April 2013

\section{http://journal.unair.ac.id/download-fullpapers-jpks1f40771783full.pdf}

Devina juwita sari. 2013. Hubungan antara dukungan sosial dengan penerimaan diri pada remaja penderita biv di Surabaya. Jurnal Penelitian Psikologi, Fakultas Ilmu Pendidikan UNESA. Vol 1, No 3 (2013)

\section{https://jurnalmahasiswa.unesa.ac.id/index.php/character/article/view/2716}

Dina Yulia Sudhar. 2010. Hubungan antara penerimaan diri dengan kompetensi interpersonal pada remaja panti asuhan. Universitas Muhammadiyah Surakarta.

\section{http://eprints.ums.ac.id/7833/}

Dini Primadewi Aris, Rinaldi. (2015) Hubungan regulasi emosi dengan penerimaan diri wanita premenopause. Jurnal Riset Aktual Psikolog UNP. Vol 6, No.1 (2015)

\section{http://ejournal.unp.ac.id/index.php/psikologi/article/view/6646}

Fatyana Indah Permata Sari. 2014. Hubungan Regulasi Emosi Ibu dengan Kecenderungan Perilaku Kekerasan Orangtua Terhadap Anak. Fakultas Psikologi Universitas Negeri Makassar 
Rany Handri Yanti ${ }^{1}$, Ria Novianti ${ }^{2}$, Enda Puspitasari ${ }^{3}$

http://eprints.unm.ac.id/404/

Felayati. 2017. Hubungan Antara Regulasi Emosi Dengan Kekerasan Ibu Yang Berasal Dari Keluarga Miskin Terhadap Anak. Fakultas Psikologi Universitas Islam Negeri Sultan Syarif Kasim Riau

http://repository.uin-suska.ac.id/21424/

Gharnish Tiara Resty. 2015. Pengaruh Penerimaan Diri Terhadap Harga Diri Remaja Di Panti Asuban Yatim Putri Aisyiyah Yogyakarta. Vol. 2, No. 1 April 2019, hal 28-34

https://s.docworkspace.com/docs/3b6fL5dR6

Gross \& Thompson. 2006. Emotion Regulation Conceptual Foundation. In J.J. Gross (ed). Handbook of emotion regulation.New York: Guilford Pers

Goleman.D. 2006. Kecerdasan Emosi Untuk Mencapai Puncak Prestasi (Terjemahan: Alex Tri K.W). Jakarta : PT. Gramedia Pustaka Utama

Intan Megasari, Ika Febrian Kristiana 2016. Hubungan Antara Dukungan Sosial Suami Dengan Penerimaan Diri Pada Ibu Yang Memiliki Anak Down Syndrome Di Semarang. Universitas Diponegoro. Vol. 5, No.4 Oktober 2016

https://ejournal3.undip.ac.id/index.php/empati/article/view/15426

John W. Santrock. 2003. Perkembangan Remaja. Jakarta : Penerbit Erlangga

Novita Dwi Aryani. 2015. Hubungan Orang Tua-Anak, Penerimaan Diri Dan Keputusasaan Pada Remaja Dari Keluarga Broken Home. Jurnal Sains \& Praktik Psikologi. Vol.3, No.1 (2015)

http://ejournal.umm.ac.id/index.php/jspp/article/view/2172

Retno Twistiandayani, Susi Ratna Handika (2015). Hubungan Dukungan Keluarga dengan Penerimaan Diri Ibu yang Mempunyai Anak. Autis. Journals of Ners Community. Vol. 6, No.2 (2015)

http://journal.unigres.ac.id/index.php/JNC/article/view/45

Ria Novianti. 2018. Orangtua Sebagai Peran Utama dalam Menummbubkan Resiliensi Anak. EDUCHILD. Pekanbaru. Vol.7, No.1 (2018)

https://ejournal.unri.ac.id/index.php/JPSBE/article/view/5101

Retty Fauzia, Ratih Arruum Listiyandini. 2018. Trait Mindfulness (Rasa Kesadaran) TerhadapPenerimaan Diri Pada Remaja Dengan Orangtua Bercerai. Fakultas Psikologi Universitas YARSI.

https://www.researchgate.net/profile/Ratih Arruum Listiyandini/publication/329041137 Peran Trait Mindfulness Rasa Kesadaran Terhadap Penerimaan Diri Pada Remaja D engan Orangtua Bercerai

Kindergarten, Vol. 2, No. 1, April 2019, Hal. 35-57 
Rany Handri Yanti ${ }^{1}$, Ria Novianti ${ }^{2}$, Enda Puspitasari ${ }^{3}$

Rofatina, Nugraha Arif Karyanta, Pratista Arya Satwika. 2016. Hubungan antara Regulasi Emosi dan Religiusitas dengan Resiliensi pada Ibu yang Memiliki Anak. Tunagrahita di SLB C YPSLB Kerten Surakarta. Wacana Jurnal Psikologi. Vol 8, No.2 (2016). http://jurnalwacana.psikologi.fk.uns.ac.id/index.php/wacana/article/view/94

Rully Nurmalita, Farida Hidayati. 2014. Hubungan Antara Regulasi Emosi Dengan Kompetensi Interpersonal Pada Remaja Panti Asuban. Fakultas Psikologi UNDIP. Vol 3, No.4 (2014) https://ejournal3.undip.ac.id/index.php/empati/article/view/7613

Tamasari, Galuh. 2019. Penerimaan Diri Remaja Terhadap Perceraian Orangtua. Universitas Ahmad Dahlan.

\section{http://eprints.uad.ac.id/15350/}

Tyas Diana Uswatun Hasanah \& Erlina Listyanti Widuri.2014.Regulasi Emosi Pada Ibu Single Mother. Jurnal Psikologi Integratif. Vol.2, No.1, Juni 2014

http://etd.unsyiah.ac.id/index.pihp.show-detail\&id

Wenny Aidina, Haiyun Nisa, Arum Sulistyani. 2013. Hubungan Antara Penerimaan Diri Dengan Optimisme Menghadapi Masa Depan Pada Remaja Di Panti Asuban. Program Studi Psikologi Fakultas Kedokteran Universitas Syiah Kuala. Vol. VI No. 2.Juli - Desember 2013

https://www.researchgate.net/profile/Haiyun Nisa/publication/325944169 Hubungan Antara P enerimaan Diri Dengan Optimisme Menghadapi Masa Depan Pada Remaja Di Panti Asuhan

Wiwien Dinar Pratisti. 2013. Peran Orangtuadalam Perkembangan Kemampuan Regulasi Emosi Anak. Fakultas Psikologi, Universitas Muhammadiyah Surakarta. https://publikasiilmiah.ums.ac.id/bitstream/handle/11617/3966/A30.pdf; sequence=1

White.B. 2012.Self Acceptance Prosess.Bloomington: Lunivers 